\title{
LA POESÍA DE LO REVACIADO. IMÁGENES DE MEMORIA, IMÁGENES DE NACIÓN
}

Wander Melo Miranda*

\begin{abstract}
RESUMEN: Reflexión sobre memoria y nación en los textos memorialistas de Carlos Drummond de Andrade (1902-1987), Murilo Mendes (19011975) y Pedro Nava (1903-1984), escritos en los años 1960-1980, como si fuera una reescritura crítica del proyecto modernista de nación, para el cual fueron unos de los principales artífices en los años 1930 en Brasil. La lectura plantea la escritura de la nación como límite y umbral de la diferencia cultural.
\end{abstract}

PalABRAs ClaVe: Memoria, Nación, Modernidad, Memorialistas brasileños.

ABSTRACT: This paper is about the subjects of memory and nation in the memorial texts of Carlos Drummond de Andrade (1902-1987), Murilo Mendes (1901-1975), and Pedro Nava (1903-1984), written in the 1960's and 1980's, as if it was a critical rewriting of the modernist project of nation of which they were some of the main promoters in the 1930's in Brazil. The reading raises the writing of the nation as a boundary and threshold of cultural difference.

KEY WORDS: Memory, Nation, Modernity, Brazilian memorialists.

La narrativa de la nación es un juego sutil entre recuerdo y olvido. Al tratar del nacimiento de las naciones europeas, Renan llama la atención sobre el hecho de que si no se olvida la violencia existente en el origen de todas las formaciones nacionales es imposible lograr la unidad que las constituye. La comunión de intereses entre los individuos es también compartir hechos que deben ser olvidados o recordados en conjunto, para que no se repitan, para que sean constantemente "olvidados". Raza, lengua, religión, territorio e intereses militares se someten a la abstrac-

* Universidad Federal de Minas Gerais, Brasil (wander@pib.com.br). 
ción de las diferencias y al principio del olvido de un disenso originario. Pero una nación no existe sin pasado: hay que recordar la herencia de sus fundadores. La memoria nacional, nos advierte Maurice Halbwachs, es la forma más depurada de la memoria colectiva. ${ }^{1}$ Su función es mantener la cohesión social y la estabilidad de las instituciones que delimitan las fronteras nacionales - es la memoria del monumento público, oficial, que se organiza alrededor de los acontecimientos y personajes históricos.

Michael Pollak, al estudiar las "memorias subterráneas", 2 recalcadas y mantenidas largo tiempo en silencio por el carácter uniformante y destructivo de la memoria colectiva nacional, subraya el proceso de redistribución de cartas políticas e ideológicas cuando tales memorias rompen la afasia y emergen. Cuando ello ocurre, operaciones de "negociación" entre las distintas memorias entran en acción, con el objetivo de mantener la unidad del tejido social en constante renovación, aunque tal procedimiento no deje de indicar el abismo existente entre las reivindicaciones de la sociedad civil y las imposiciones del Estado-nación hegemónico.

En este caso, parece pertinente relacionar la aludida negociación con la metáfora del "plebiscito diario", 3 que Renan usa para definir la nación. Ambas reúnen la herencia del pasado con un futuro a realizar, a través de la expresión del deseo presente de continuar viviendo en común. La dualidad que la metáfora del plebiscito expresa merece atención, ya que condensa dos tiempos distintos de una misma realidad. El plebiscito afirma por una parte un conflicto anterior, que debe ser rodeado o asumido diariamente por el consenso de los individuos, y por la otra, la

1 Cfr. Maurice Halbwachs, La mémoire collective, París, Presses Universitaires de France, 1950.

2 Michael Pollak, "Memória, esquecimento, silêncio", Estudos Históricos, vol. 2, núm. 3, Río de Janeiro, 1989, pp. 3-15.

3 Ernest Renan, Qu'est-ce qu'une nation? Conférence faite en Sorbonne, le 11 mars 1882, vol.I. Para un contrapunto a ese argumento, véase, por ejemplo, Tzvetan Todorov, Nous et les autres; la refléxion francaiçaise sur la diversité humaine, París, Sevil, 1989, pp. 247-261. 
emergencia de algo nuevo en el curso de la vida cotidiana que, siendo hasta cierto punto inevitable, debe ser convenientemente dirigido para la manutención de la unidad social.

En otros términos: el pueblo crea la nación y es creado por ella, configurando una amalgama - la "conciencia moral", en la expresión de Renan - que muestra que el hombre "no es esclavo de su raza, ni de su lengua, ni de su religión, ni del curso de los ríos, ni de la dirección de las cadenas de montañas". Aunque tales elementos hagan parte del conjunto de referentes que constituyen una nación o el ser nacional desde una perspectiva de lo alto (gobiernos o militantes nacionalistas), ellos sólo adquieren función significativa atravesados por lo bajo, ${ }^{5}$ por intereses, suposiciones y aspiraciones de personas comunes. El punto de intersección de la política (institucional) con las transformaciones socioculturales en curso da a la clásica ecuación nación=Estado=pueblo soberano una movilidad bastante específica. En verdad, las narrativas de identidad nacional se construyen, dentro del ámbito de una concepción pedagógica, por la negociación constante del principio que reafirma el interés general en contra de los intereses particulares, el bien común en contra del privilegio. Es decir: el sueño de una sociedad de pares incluye la represión de la diferencia del sujeto, a cambio de la libertad individual dentro de la comunidad mantenida a salvo del peligro de disolución de los intereses corporativos o "tribales". ${ }^{6}$ La conocida declaración del fallecido líder revolucionario Samora Machel "Matar la tribu para que nazca la nación mozambicana", aunque remita a un acontecimiento histórico específico, expresa de manera general el proceso determinante de las formaciones nacionales $\mathrm{y}$, a la vez, el factor de homogeneización (violenta) que casi siempre lo preside.

4 Renan, op. cit., p. 905.

5 Las categorías de alto y bajo remiten a Eric J. Hobsbawn, Nações e nacionalismo desde 1780, trad. Maria Célia Paoli e Anna María Quirino, Río de Janeiro, Paz e Terra, 1990, p. 20.

6 Cfr. Contardo Calligaris, "Da nação ao triunfo das tribos", Folha de S. Paulo. Ilustrada, marzo, 1994, p. 13. 
En el conjunto de las identificaciones que constituyen el ser social en la actualidad, el conflicto inevitable entre lo global y lo local parece reafirmar la vía de identificación nacional basada en la concepción de que lo distinto es igual, aunque no idéntico. ${ }^{7}$ La emergencia reivindicatoria de las minorías — sexuales, étnicas, religiosas - torna visible tal concepción en el ámbito de lo cotidiano, dando al aludido plebiscito diario una complejidad antes insospechada. Si la frontera es lo que distingue una nación de lo que está fuera de ella - el territorio del Otro-, el discurso minoritario señala la existencia de fronteras internas, que demarcan el espacio heterogéneo de la identidad que debe ser compartida. La identificación resulta, por lo tanto, en un movimiento dual de estrechamiento y ensanchamiento de fronteras culturales, considerándose los "territorios" que deben ser cedidos o conquistados en los intersticios de las diferencias sociales y las luchas políticas. En este sentido, la integración nacional pasa a depender más de la agonística de los valores en juego en la escena social que de las estrategias puestas en funcionamiento por el aparato ideológico del Estado.

El juego de diferencias e identificaciones que compone la idea de nación implica también la existencia de un régimen temporal propio. Como lo ha demostrado Benedict Anderson, la imaginación nacionalista guarda fuertes afinidades con la inmortalidad y la muerte. El autor subraya la importancia de los cenotafios y tumbas de soldados desconocidos para la "comunidad imaginada" que es la nación, ${ }^{8}$ al afirmar que el significado cultural de tales monumentos radica en el hecho de que están vacíos de restos mortales identificables y pueden entonces comportar las fantasmagóricas proyecciones nacionales.

Esa suerte de vacío operatorio hace que la fatalidad se transforme en continuidad, el acaso en destino. En el sistema simbólico así instituido,

7 Cfr. Massimo Canevacci, "Antropólogo italiano cria o "etno-cyberpunk", Folha de S. Paulo. Ilustrada, 6 de septiembre, 1995 (Entrevista a Elvis César Bonassa), p. 8.

8 Cfr. Benedict Anderson, Nação e consciência nacional, trad. Lólio L. Oliveira, Sao Paulo, Ática, 1989, p. 17. 
los muertos se vinculan a los vivos y a los que van a nacer, dando un significado de perennidad a lo que es contingente, como si la "historia" de la nación emergiera desde siempre de un pasado inmemorial. Pero en el caso de la imaginación nacionalista, la concepción religiosa de la simultaneidad longitudinal del tiempo, que vincula un aquí y ahora a algo que ha existido siempre y que se cumplirá en el futuro, cede lugar a la idea del "tiempo homogéneo y vacío". ${ }^{9}$ Esa idea traduce, en términos mundanos y seculares, la herencia hebraico-cristiana, que concibe la historia como historia de la salvación y sus corolarios - creación, pecado, redención y espera del juicio final. La simultaneidad pasa entonces a ser marcada por la coincidencia temporal ${ }^{10}$ de la vida en común, que debe ser medida por el reloj y los cronómetros. En palabras de B. Anderson,

La idea de un organismo sociológico que se mueve por el calendario a través del tiempo homogéneo y vacío presenta una analogía precisa con la idea de nación, también concebida como una comunidad compacta que se mueve firmemente a través de la historia. ${ }^{11}$

Tal movimiento, pautado por la linealidad y la acumulación, expresa el cambio radical operado por la modernidad en el ámbito de la vida social y de las prácticas culturales en las que se incluye la literatura. Una aproximación, aunque sumaria, a Baudelaire es en este punto aclaradora. Para el autor de Les Fleurs du Mal, el reloj de los tiempos modernos es un "dieu sinistre, effrayant, impassible", proveído de un "gosier de métal" que devora todo: los placeres, los días. Dios-autómata, que señala, a través de la repetición acumulativa y la aceleración impuesta por la producción capitalista, el tiempo deshumanizado de la enajenación que lleva el nombre de progreso. En el último poema de Spleen et Idéal, el

9 Ibid., p. 33. Sobre el tiempo homogéneo y vacío, véase Walter Benjamin, "Sobre o conceito de história", en Magia e técnica, arte e politica, trad. Sérgio Paulo Rovanet, Sao Paulo, Brasiliense, 1993, p. 229.

${ }_{10}$ Para Anderson, la fecha en la página del periódico cotidiano es la marcación regular del pasaje del tiempo homogéneo y vacío. Cfr. Anderson, op. cit., p. 42.

11 Ibid., p. 35. 
lírico en el auge del capitalismo convierte el encadenamiento regulado por el flujo continuo de la historia universal en catástrofe y desastre del futuro, a causa de la lógica misma de constitución del tiempo de lo moderno como "avénement du neuf". ${ }^{12}$ Dice el poeta, en "L'horloge":

Trois mille six cents fois par heure, la Seconde

Chuchote: Souviens-toi! - Rapide, avec sa voix

D'insecte, maintenant dit: Je suis Autrefois,

Et j'ai pompé ta vie avec ma trompe immonde! ${ }^{13}$

Souviens-toi! - la ecuación temporal del poema asimila, en la expresión que la constituye y que se repite intermitentemente, el llamado a la reminiscencia y a la comprobación de su imposibilidad en el tiempo homogéneo y vacío en que lo nuevo, en tanto novedad burguesa, se ha erigido como valor absoluto. Memoria y modernidad expresan, en la forma de la conjunción disyuntiva, el desgarramiento baudelaireano y, en última instancia, la intervención paradójica del poeta que busca "oponer al tiempo destructor la frágil perennidad del poema". ${ }^{14} \mathrm{El}$ acto poético, revolucionario por excelencia, inscribe en el cuerpo textual las marcas de su radicalidad: la advertencia reiterada (Souviens-toi!), además de la grafía diferencial que la distingue en la cadena significante, funciona como una suerte de cesura que interrumpe el encadenamiento rítmico de los versos e instaura un instante de pausa en la lectura. La pausa captura el tiempo y concentra, en el momento de la reminiscencia, la posibilidad de salvar la memoria involuntaria de la historia. La conciencia aguda de la temporalidad y de la muerte introduce, en la masa uniforme de los días y en el lenguaje, la capacidad de percibir lo diferenciado y hacerlo vibrar con la intensidad de una mónada. Esa parada brusca inmoviliza el presente que contiene, en su "ahora", el devenir histórico — como en el acto de los

12 Charles Baudelaire, Curiosités esthétiques, París, Louis Conard, 1923, "Salon de 1845 ", p. 78.

${ }_{13}$ Charles Baudelaire, Les Fleurs du mal, París, Armand Colin, 1958, p. 86.

14 Jeanne Marie Gagnebin, História e narração em Walter Benjamin, Sao Paulo, Perspectiva, 1994, p. 61. 
manifestantes franceses de la Revolución de julio, que nos recuerda W. Benjamin, ${ }^{15}$ al disparar sus armas, a la misma hora y sin acuerdo previo, sobre los relojes de las torres localizadas en diferentes barrios de París. En el orden de la escritura, interrumpir la progresión lineal del tiempo es, de cierta manera, desencadenar el acontecimiento revolucionario de la descentralización del sujeto. Ya no su restricción al valor positivo de una presencia o a la conciencia de sí mismo, sino más bien la apertura a las dimensiones involuntarias e inconscientes de la experiencia de la cual se ha visto expoliado con el advenimiento de lo moderno. La memoria, en cuanto forma de determinación histórica de esa experiencia a punto de desaparecer, cumple ahí la función operatoria de temporalizar el espacio, mediante la marcación de intervalos, pausas o suspensiones que interrumpen la linealidad cronológica y la identidad del sujeto consigo mismo, insertándolo en un registro temporal diferenciado. La apertura a lo que es otro y no-propio deshace la existencia de una interioridad o una anterioridad absolutas, pautadas por la oposición entre dentro y fuera, singular y anónimo. En el enredo de las ramificaciones y conexiones que se hacen por contigüidad, el tiempo atraviesa al sujeto y es atravesado por él, tornando el poema (flor del mal) la promesse de bonheur de otra historia.

El impasse en la noción de identidad del sujeto moderno, que la poesía baudelaireana traduce en términos de "destrucción de la memoria" ${ }^{16}$ expresa la inestabilidad de los regímenes de identificación que atraviesan tanto la experiencia particular cuanto la experiencia colectiva, en rigor indisociables. En el caso de la escritura de memorias, emprender la búsqueda de sí equivale a tomar la memoria como lugar de conciencia biográfica e histórica del presente, a partir de imágenes generadas por lo que falta o se ha perdido. Es lo que enuncia el poema "Documentário", de Carlos Drummond de Andrade:

${ }^{15}$ Cfr. Benjamin, op. cit., p. 231.

${ }_{16}$ Wille Bolle, Fisiognomia da metrópole moderna, Sao Paulo, Edusp, 1994, p. 345. 
No Hotel dos Viajantes se hospeda incógnito.

Já não é ele, é um mais tarde

sem direito de usar a semelhança.

Não sai para rever, sai para ver

o tempo futuro

que secou as esponjeiras

e ergueu pirâmides de ferro em pó

onde uma serra, um clã, um menino

literalmente desapareceram

e surgem equipamentos eletrônicos.

Está filmando

seu depois.

O perfil da pedra

sem eco.

Ao sobrados sem linguagem.

A nova humanidade deslizando

isenta de raízes.

Entre códigos vindouros

a nebulosa das letras

indecifráveis nas escolas:

seu nome familiar

é um chiar de rato

sem paiol

na nitidez do cenário

solunar.

Tudo registra em preto-e-branco

afasta o adjetivo da cor

a cançoneta da memória

o enternecimento disponível na maleta.

A câmara

olha muito olha mais e capta

a inexistência abismal

definitiva/infinita. ${ }^{17}$

17 Carlos Drummond de Andrade, Menino antigo, Río de Janeiro, Sabiá, 1973, pp. 3-4: En el Hotel de los Viajantes se hospeda/incógnito./Ya no es él, es un más-tarde/sin derecho a usar la semejanza./No sale a rever, sale a ver/el tiempo futuro/que secó las esponjeras/e irguió pirámides de hierro en polvo/donde una sierra, un clan, un niño,/ literalmente desaparecieron/y surgen equipajes electrónicos./Está fotografiando/su 
El tópos del viaje es indicador del desplazamiento entre espacios separados por el tiempo, así como del efecto de extrañeza del viajante que se aleja de sí para tener la experiencia del otro en el que, en buena medida, él se ha convertido. Ponerse en el centro de la cámara del poema-película-documento es estar fuera de sí para verse desdoblado en un tiempo no secuencial, efecto del movimiento mismo de vuelta a un futuro anterior, al pasado como una "edad venidera". ${ }^{18}$ La adopción de una perspectiva a posteriori imprime en el negativo del poema-película las imágenes virtuales que van a documentar el exilio del sujeto en el territorio indefinido e inestable de la "nueva humanidad", cuyas huellas, como raíces aéreas, el lenguaje de la memoria se encargará de recrear. La fuerza de evocación y prospección de la muerte - ausencia abismal/infinita - hace converger itinerarios en principio divergentes: el camino hacia atrás del adulto que recuerda y del niño que camina hacia adelante en la vida. ${ }^{19}$

La postura asumida por el poeta de Boitempo, al introducir la percepción infantil como determinante del proceso de rememoración, tiene consecuencias que van más allá de la mera reconstrucción biográfica de una infancia empírica. Como observa Silviano Santiago,

Drummond, al querer volver a ser niño, no lo hace con el deseo de ver al niño que existe en el adulto, sino con el deseo de ver al niño que existe en el niño, con el deseo de ver al viejo que existe en el niño, o, de manera

después./El perfil de la piedra/sin eco./Las casonas sin lenguaje./El pensamiento descarnado./La nueva humanidad deslizando/exenta de raíces./Entre códigos venideros/la nebulosa de letras/indecifrables en las escuelas:/su nombre familiar/es un chillar de ratón/sin granero/en la nitidez del escenario/sólunar./Todo lo registra en blanco y negro/aparta el adjetivo del color/la cancioncilla de la memoria/el enternecimiento disponible en la maleta./La cámara/mira mucho mira más/y capta/la inexistencia abismal/definitiva/infinita.

18 Octavio Paz, Os filhos do barro, trad. Olga Savary, Río de Janeiro, Nova Fronteira, 1984, p. 28.

19 Cfr. Bolle, op. cit., p. 324. 
más definitiva, con el deseo del niño que es el viejo, o el viejo que es el niño. ${ }^{20}$

El lastre de la historia personal no resulta de la coincidencia entre el evento y su registro en el transcurso del tiempo homogéneo y vacío, sino de la posibilidad de establecer correspondencias inesperadas entre el pasado y el presente, o entre lo nuevo y lo viejo. La vía elegida es la adopción deliberada del ritmo de una suerte de durée de la "vida parroquial", como forma de cuestionar a la sociedad urbano-industrial y al mundo tecnológico. No se trata del retorno conservador "a las tablas de la ley 'mineira' de familia" o al "Antiguo Testamento del Brasil", ${ }^{21}$ sino del comentario y la distorsión irónica de sus códigos por la insistencia del adulto en asumir la voluptuosidad del niño, como deja claro el poema "Intimação", de Esquecer para Lembrar. Variante de la "ivresse" baudelaireana — "L'enfant voit tout en nouveauté; il est toujours ivre"_-22 la voluptuosidad torna oscilante el foco de observación (hacia adelante, hacia atrás), como si todo fuera visto siempre por primera vez.

La reconstitución incesante del gesto arcaico y nuevo de recomenzar, en tanto forma de rastrear la pérdida irremediable del origen, apunta hacia el encuentro con una vida anterior o prehistórica, simulada como lugar de las inesperadas correspondencias que la historia lineal porfía en olvidar. Es el tiempo de la escritura del adulto-niño, de la salvación de la experiencia por la mémoire involontaire de lo desconocido. La percepción infantil se vuelve estado de creación poética. En "Inscrições rupestres no Carmo", el niño, caminando hacia la escuela, se ve delante de dibujos indígenas sobre la piedra. Presiente en ellos un patrimonio

20 Silviano Santiago, "Discurso memorialista de Drummond faz a síntese entre confissão e ficção", Folha de S. Paulo. Ilustrada, 7 de abril, 1990, p. 5.

21 Véase respectivamente, los poemas "O beijo" y "Justificação", en Andrade, Menino antigo..., pp. 91 y 7.

${ }_{22}$ Charles Baudelaire, Oeuvres complètes, París, Louis Conard, 1925, "Le peintre de la vie moderne", p. 59. 
de valor más grande que los bienes de familia, aunque no vinculado a su experiencia personal ni a la de sus contemporáneos: ${ }^{23}$

É um tempo antes do tempo de relógio, e tudo se recusa a ser História e a derivar em provas escolares. Lá vou eu, carregando minha pedra, meu lápis, minha turva tabuada, rumo à aula de insípidos ditados, cismando nesses mágicos desenhos que bem desenharia, fosse índio. ${ }^{24}$

El tiempo de las memorias drummondianas se marca por la aparición y el apagamiento de esos dibujos que perduran como imágenes estelares, en la liviandad porosa de la hoja de papel. Apropiarse del curso de las cosas es resignarse a perderlas, lo sabe bien el memorialista, para quien el texto es el lugar de la significación y de la muerte. La recusación al estilo clásico de la autobiografía, a favor del fragmento y la discontinuidad, expresa ese recorrido de pérdidas y ganancias, haciendo de la reminiscencia el doblar y desdoblar de lo insignificante, lo nimio y lo particular. Lo memorable adviene, pues, de residuos culturales que el adulto-niño, en su condición inaugural, articula con su propia experiencia: el viajante se desdobla en arqueólogo y coleccionista. El poema "Coleção de cacos", en Esquecer para Lembrar, sintetiza bien la situación

Já não coleciono selos. $\mathrm{O}$ mundo me inquizila.

Tem países demais, geografias demais.

Desisto.

Nunca chegaria a ter um álbum igual ao do Dr. Grisolia,

23 "[...] cuál es el valor de todo nuestro patrimonio cultural, si la experiencia ya no lo vincula a nosotros?". Benjamin, "Experiência e pobreza"..., p. 15.

${ }^{24}$ Carlos Drummond Andrade, Esquecer para Lembrar, Río de Janeiro, José Olympio, 1979, p. 15: Es un tiempo antes del tiempo del reloj,/Y todo rehusa a ser Historia/Y a derivar en pruebas escolares./Allá voy yo, cargando mi piedra,/mi lápiz, mi turbia tabla,/hacia la clase de insípidos dictados,/devaneando sobre esos mágicos dibujos/ qué bien dibujaría, si fuera yo indio. 
orgulho da cidade.

E toda gente coleciona

os mesmos pedacinhos de papel.

Agora coleciono cacos de louça

quebrada há muito tempo.

Cacos novos não servem.

Brancos também não.

Têm de ser coloridos e vetustos, desenterrados — faço questão — da horta.

Guardo uma fortuna em rosinhas estilhaçadas, restos de flores não conhecidas.

Tão pouco: só o roxo não delineado, o carmezim absoluto,

o verde não sabendo

a que xícara serviu.

Mas eu refaço a flor por sua cor,

e é só minha tal flor, se a cor é minha

no caco de tigela.

$\mathrm{O}$ caco vem da terra como fruto

a me aguardar, segredo

que morta cozinheira ali depôs

para que um dia eu o desvendasse.

Lavrar, lavrar com mãos impacientes

um ouro desprezado

por todos da família. Bichos pequeninos

fogem de revolvido lar subterrâneo.

Vidros agressivos

ferem os dedos, preço

de descobrimento:

a coleção e seu sinal de sangue;

a coleção e seu risco de tétano;

a coleção que nenhum outro imita.

Escondo-a de José, por que não ria

nem jogue fora esse museu de sonho. ${ }^{25}$

${ }^{25}$ Ibid., pp. 44-45: Ya no colecciono sellos. El mundo me aburre. /Tiene demasiados países, demasiadas geografías./Desisto./Nunca llegaría a tener un álbum igual al del Dr. Grisolia,/orgullo de la ciudad./Y toda la gente colecciona/los mismos pedacitos de papel./Ahora colecciono briznas de loza/quebrada hace mucho tiempo./Briznas nuevas no sirven./Blancas tampoco./Tienen que ser coloridas y vetustas,/desenterradas 
La lógica del coleccionista se sirve de la singularidad, se opone a lo típico y lo clasificable, actuando contra la cosificación, que es una forma de olvido. El trabajo arqueológico de anamnesis opera por cortes y recortes en el continuum de la historia -individual o colectiva- modificando lo ya fijado y estableciendo un nuevo orden correlativo, que se añade a un significado precedente (la colección de sellos, la loza entera). Aristas cortantes de sentido, las briznas se suceden metonímicamente como fragmentos, sin jamás constituir, sin embargo, una totalidad. El "museo de sueño" o museo imaginario que es la colección recupera a través del fragmento el aura del objeto - lo que es irrepetible y único - tornando próximo lo lejano. De ahí viene la "iluminación profana" en que, en las palabras de Olgária Matos, "lo cotidiano y el misterio conjugan sus poderes, haciendo cuerpo con el mundo de las imágenes (Bild). Es en la imagen donde 'telescopian' lo inmemorial del pasado y el Jetztzeit"'. ${ }^{26}$

La tensión entre presencia y ausencia, inherente a la constitución de la imagen como tal, configura la escritura de las memorias como un movimiento de aproximación a lo que está lejano en el tiempo, a lo que está lejano en el espacio. Coleccionar briznas y contar historias se afirman como actividades análogas, ya que se definen por una suerte de ritual de revivificación en el que la imagen-fragmento, además de evidenciar la distancia del pasado y el deseo de redimirlo por el presente, se revela

— hago hincapié - de la huerta./Guardo una fortuna en rositas destrozadas,/restos de flores no conocidas./Tan poco: sólo el violeta no delineado,/el carmesí absoluto,/el verde no sabiendo/a qué tazón sirvió./Pero yo rehago la flor por su color,y es sólo mía tal flor, si el color es mío/en la brizna del tazón./La brizna viene de la tierra como fruto/que me aguarda, secreto/que la muerta cocinera allí ha depositado/para que un día yo lo desvelara./Labrar, labrar con manos impacientes/un oro despreciado/por todos en la familia. Bichos pequeñitos/huyen de revuelto hogar subterráneo./Vidrios agresivos/hieren los dedos, precio/del descubrimiento:/la colección y su señal de sangre;/la colección y su riesgo de tétano;/la colección que nadie más imita./La oculto a José, para que no se ría/ni eche a rodar ese museo de sueño.

${ }^{26}$ Olgária C.F. Matos, Os arcanos do inteiramente outro, Sao Paulo, Brasiliense, 1989 , p. 92. 
como representación disyuntiva del espacio social. La autoinserción del coleccionista-narrador ${ }^{27}$ en una tradición subterránea y escondida - que el secreto de la cocinera encierra - instituye una vía oblicua de imágenes de identidad que ponen en escena la alteridad de los individuos y de la cultura. A través de ese proceso, se vuelve patente la falta anterior de una presencia - un "vacío sin vaso", ${ }^{28}$ en palabras de Drummond - que incide metonímicamente sobre la metáfora de la unidad social y la homogeneización cultural. La singularidad del coleccionista de briznas respecto a los demás coleccionistas hace manifiesta otra geografía, que delinea el espacio de resistencia a la totalización, en el plano del hombre individual y en el plano de la colectividad.

La escritura de memorias, forma peculiar de la narrativa de identidad, permite observar cómo opera la conjunción que delimita la nación moderna, simultáneamente "colección de individuos e individuo colectivo", según Louis Dumont. ${ }^{29}$ De hecho, el memorialista estaría escenificando su necesidad de emancipación individual al diferenciarse de los demás, a la vez que se reconocería inmediatamente como ser social, siendo normal su necesidad de acotarse y entrar en comunión. Desde ese punto de vista la aporía de la nación traduce, todavía según L. Dumont, "la dificultad que tiene la ideología moderna de dar una imagen suficiente de la vida social (intra e intersocial)", ${ }^{30}$ sobre todo al pensarla en términos genéri-

27 Sobre la narratividad de los poemas de Boitempo véase José Guilherme Merquior, "Notas em função de Boitempo (1)", en Acústica da mímese, Río de Janeiro, José Olympio, 1972, p. 47.

${ }^{28}$ Carlos Drummond Andrade, Boitempo \& A falta que ama, Río de Janeiro, Sabiá, 1968, p. 53.

${ }^{29}$ Cfr. Louis Dumont, $O$ individualismo; uma perspectiva antropológica da ideologia moderna, trad. Álvaro Cabral, Río de Janeiro, Rocco, 1985, pp. 138-139.

${ }^{30}$ Ibid., p. 139. 
cos de causalidades discursivas previamente dadas. Por singularizar la totalidad del espacio de la nación a través de la perspectiva personal, las memorias se oponen al poder de generalización implícito en la metáfora generadora de la solidez y cohesión nacionales — la de "muchos como uno"-, abriendo grietas para otras posibilidades de rearticulación de identidad. Para decirlo con H. Bhabha, en la nueva situación, el uno es no solamente la tendencia para totalizar lo social en el tiempo homogéneo y vacío, sino también la repetición de menos uno en el origen, el menosque-uno que interviene como una iterativa temporalidad, en el sentido de transformar lo unísono del Heim nacional en unheimlich. ${ }^{31}$ Es lo que Murilo Mendes deja entrever en el pasaje de A Idade do Serrote.

Todos se conocían. Juiz de Fora parecía constituir una sola familia. Brasil era inmenso, lejano, indeterminado, casi abstracto; el monte del Imperador, alto a mis ojos como el Himalaya, me daba la idea de límite intransponible, haciéndome comprender que vivíamos en una suerte de prisión de lujo. Yo quería que mi padre construyera una casa en lo alto del monte; pedía a Primo Nelson que lo convenciera; porque viviendo allá arriba se alteraría ciertamente mi idea de límite; estaría más cerca de las nubes, tal vez podría charlar con seres sobrenaturales; gozaría de amplia perspectiva. ${ }^{32}$

El principio desagregador que separa continente y contenido, desplazando hacia fuera del territorio familiar de la patria chica el espacio de la nación lejana, es aquí índice del deseo y de la frustración de constituirse en núcleo común de identidad, que debe ser compartido en la "amplia perspectiva" del Brasil. Al situarse dentro y fuera de las fronteras nacionales, el narrador muriliano - también él un adulto-niño, aunque investido de larga erudición cosmopolita - reafirma en el ámbito de las memorias una falta que sólo puede ser colmada (vicariamente) mediante el suplemento de la escritura. De esta manera, las memorias traen a la

31 Cfr. Homi K. Bhabha [org.], Nation and Narration, Londres/Nueva York, Routledge, 1990, "DissemiNation: time, narrative and the margins of the modern nation", p. 315.

${ }^{32}$ Murilo Mendes, A Idade do Serrote, Río de Janeiro, Sabiá, 1968, p. 74. 
escena del texto, a través de distintos procedimientos alegóricos, efectos de "desterritorialización" que se desdoblan en imágenes cada vez más ambiguas en términos de localización espacial. En otro pasaje de $A$ Idade do Serrote, refiriéndose a su niñera, el narrador da una buena humorada muestra de eso: "Sebastiana dice que tiene un deseo loco de irse a Minas Gerais. Mamá dice pero Sebastiana tú vives en Minas Gerais, oh gente, yo pensaba que yo vivía en Juiz de Fora". ${ }^{33}$

La idea de Minas como el "círculo geográfico del centro" 34 parece contradecir la referida ambigüedad, si no fuera porque tal concepción de centralización conforma un índice de la tendencia histórica del separatismo de algunas de las regiones "mineiras". El artificio de la centralización adquiere, aun sin proponérselo, un poder de exclusión que contraría construcciones ideológicas basadas en la premisa de la resolución armónica de los conflictos y en la visión conciliadora que, en un libro famoso, Alceu Amoroso Lima contribuyó a refrendar, cuando concluye que Minas estaría "naturalmente destinada a ser el centro de gravedad de Brasil". ${ }^{35}$ Pero es el memorialista Pedro Nava quien mejor va a tener en jaque la metáfora de "muchos como uno", expresando, con un marcado acento de "barrio" y prejuicio regional, la violencia del impasse entre desgarramiento y cohesión. ${ }^{36}$ En Baú de Ossos, Nava opta por el punto de vista excluyente de Minas de minerías - el "círculo mágico en donde se habla la lengua del uai", según el autor:

En el fondo, bien en el fondo, Brasil para nosotros es una expresión administrativa. El resto mismo de Minas, una convención geográfica. ¿El Triángulo ya no ha querido desprenderse y juntarse a São Paulo? Que se

33 Ibid., p. 20.

34 Antonio Candido, "Painel Minas não há mais?", en Seminário sobre a economia mineira, 1, Diamantina (MG), 1982, p. 29.

35 Alceu Amoroso Lima, Voz de Minas, $2^{\mathrm{a}}$ ed., Río de Janeiro, Agir, 1946, p. 235. Véase, sobre ese tema, Helena Bomeny, Guardiães da razão; modernistas mineiros, Río de Janeiro, Ed. UFRJ, 1994, pp. 18 y ss.

36 Véase, sobre ese tema, Wander Melo Miranda, "Memória e nação", Cenário. Psicanálisis e cultura, núm. 3, Belo Horizonte, 1994, pp. 148-156. 
desprendiera[...] ¿Y el Norte ya no ha pretendido separarse en un estado que se llamaría Nueva Filadelfia y tendría Teófilo Otoni como capital? Que se separara[...]. ${ }^{37}$

¿Qué Minas son esas que no se integran en una imagen estable y en qué suelo sino en el de la ideología se enraiza el mito de la "mineiridade"? Si la fijación en el lugar de nacimiento es la mediación privilegiada en el proceso de identificación de los memorialistas "mineiros", tal vía identificatoria se presenta llena de contradicciones, cuando se la considera como medio obligatorio de pasaje hacia la concepción de la identidad cultural brasileña. La opción crítica por la "mineiridade" como modelo interpretativo se muestra insatisfactoria una vez que, al ponerse en operación, tal modelo acaba generalmente por reforzar estereotipos como la nostalgia del origen, la reiteración de los valores de la familia patriarcal, la aversión a los cambios sociales y la incorporación de una temporalidad mítica y abstracta. ${ }^{38}$ Se trata, en suma, de endosar la idea de tradición en cuanto permanencia y conservación, lo que no llega a cumplirse en las memorias de los autores mencionados.

Otra perspectiva de lectura se esboza de modo más acuciante, si se toma en cuenta no sólo la temática de las memorias, sino también el tiempo histórico de su producción y los mecanismos literarios de enunciación textual. Una primera coincidencia de fechas no deja de ser sugestiva: A Idade do Serrote, de Murilo Mendes, y Boitempo, de Carlos Drummond de Andrade, fueron publicados en el año emblemático de 1968, el mismo del inicio de la redacción de Baú de Ossos, como indican las fechas registradas al final del libro. Visto con ojos de hoy, el hecho merece destacarse, ya que permite leer el texto tardío de los modernistas "mineiros" como una forma de intervención "performativa" en el ámbito de las representaciones de lo nacional, impuestas de manera

37 Pedro Nava, Baú de Ossos, 5a ed., Río de Janeiro, José Olympio, 1978, pp. 103 y 111.

38 Véase la lectura de los memorialistas "mineiros" efectuada en Maria A do Nascimento Arruda, Mitologia da mineiridade, Sao Paulo, Brasiliense, 1990, pp. 198-213. 
autoritaria por vía pedagógica, con ocasión del recrudecimiento de las fuerzas totalitarias en el país. Pero el hecho es más complejo de lo que parece. Desde el ángulo de la llamada "mineiridade", las memorias de los autores citados correrían - dicho de grosso modo - el riesgo que parece correr la obra de Pedro Nava, o sea, de tender a funcionar, según Davi Arrigucci Jr.,

como una justificación del presente apoyándose en la memoria del pasado, obedeciendo a una necesidad histórica de la burguesía [...] de remontar al origen reconstituyéndolo de acuerdo con su perspectiva interesada de clase, a fin de sancionar la dominación actual. Y la reconstrucción del pasado de una clase, determinado por sus intereses particulares, tendería a rebasar sus límites para confundirse con la propia historia general de la nación. ${ }^{39}$

En este sentido, las memorias continuarían siendo parte del proyecto en el que se involucraran, anteriormente, escritores como Carlos Drummond de Andrade y otros integrantes de su generación: construir una nación y darle una identidad cultural. Desde los años treinta, como sabemos, el proyecto pasa por la connivencia del intectual o del artista con la política impuesta por el "Estado Novo" para el área de la cultura, en cuyo contexto la "mineiridade" va a instituirse como una versión privilegiada del pensamiento moderno en Brasil. ${ }^{40}$ Decisiva para el proceso de modernización en curso en esa época, la tarea de sistematizar el pasado y constituir una tradición nacional encontraría, en las memorias publicadas desde finales de los años sesenta, una suerte de reiteración del antiguo proyecto, en el momento en que muchas de sus propuestas empiezan a perder la función dominante que venían ejerciendo hasta entonces, principalmente en el campo artístico y literario.

Así consideradas, las memorias tornarían anticuado lo viejo y conservadora la propia tradición modernista, en un movimiento de retorno

39 Davi Arrigucci Jr., "Móbile da memória”, en Enigma e comentário, Sao Paulo, Companhia das Letras, 1987, p. 99.

${ }^{40}$ Cfr. Bomeny, op. cit., p. 173. 
inevitable de lo mismo, si no fuera por el papel de narrador que los memorialistas asumen. Narrar es crear, a través del habla del niño que el adulto ha sido y continúa siendo, pasajes y vías de comunicación entre pasado y presente, entre dentro y fuera (de la tradición, de la nación), lo que sólo puede ser hecho recurriendo a las palabras. Encadenar una palabra o una historia en otra es fundar con el lector una comunidad narrativa - imaginada, como efecto de un deseo que se traduce en imágenes de un tiempo lleno de ahoras. Habilidoso artesano-narrador, el memorialista restaura por derivación el gesto inaugural que instituye su práctica, al hacer de ella el acto de colocar el vacío originario en forma de lenguaje. Entre el alejamiento y la pertenencia Minas se vuelve entonces una metáfora suspendida: lugar de transporte y travesía de imágenes que no se dejan inmovilizar y donde la tradición se afirma como "tra-dizione", en el sentido de transmisión e interpretación de mensajes. ${ }^{41}$

Podemos entender así el "consejo" (benjaminiano) de los viejos modernistas "mineiros", en la medida en que postulan la sobrevivencia del narrador como instancia de interacción entre distintas generaciones, consideradas como posibles sujetos de un proceso de significación "performativa", en vez de objeto histórico de una pedagogía nacionalista. No se trata, por lo tanto, de la generalización de una modalidad de saber o de la homogeneización implícita de la experiencia, en busca de la cohesión unificadora de las fuerzas discursivas en juego en la narrativa de la nación, como pretendía el proyecto de los años treinta. Al contrario, lo que interesa es el extrañamiento de las representaciones de lo nacional derivadas de él, mediante la introducción de la "individualidad" de la nación, es decir, del desplazamiento de los contenidos sociales y culturales que le son consignados a ella como un todo por el discurso histórico. La subjetividad propia de la escritura de memorias ejerce ahí la función de desreglar el tiempo autogenerador de la nación, segmentándolo al punto de reducirlo a las huellas de la experiencia individual y social

41 Sobre la noción de "tra-dizione", cfr. Gianni Vattimo, La fine della modernità, Milano, Garzanti, 1987, p. 35. 
rememoradas. Huellas son vestigios de pasajes, pero permanecen como restos que remiten a dos registros temporales heterogéneos. Por un lado, para funcionar como sustituto, una huella debe ser una señal dejada por alguna cosa, siendo algo presente cuyo contexto pasado ya no existe; por otro lado y que nos interesa aquí, la huella sólo existe para quien considera tal señal como un signo presente de una cosa ausente, como vestigio de un pasaje que ya tampoco existe y tal vez nunca existió. Seguir una huella —o escribir memorias - significa efectuar la mediación entre el ya-no del pasaje y el todavía del signo: el pasado no es sólo negativamente lo que acabó, sino lo que no terminado, de haber sido, es preservado en el presente. ${ }^{42}$

La experiencia del tiempo del signo, tal como se configura en las memorias, presenta una alternativa diferenciada para escribir, en términos literarios, la nación. La eficacia de la escritura no depende, está claro, de su coincidencia con el modelo narrativo construido por la historia nacional, sino más bien de las posibilidades que deja abiertas para estar siempre (des)articulando las nuevas relaciones significantes de la nación - fiel a su sentido etimológico de natio, nacer. En el poema "Chamado geral", de Drummond, la llamada a un nuevo nacimiento se hace oír mediante una convocación "corográfica":

Onças, capibaras, pacas, tamanduás da [corografia do Padre Ângelo de 1881, [cutias, qauits, raposas, preguiças, papa[méis, onde estais, que vos escondeis?

Mutuns, jacus, jacutingas, siriemas, araras, pa-

[pagaios, periquitos, tuins, que não ve-

[jo nem ouço, para onde voastes que vos [dispersastes?

Inhapins, gaturamos, papa-arrozes, curiós, pin[tassilgos da silva amena, onde tanto se [oculta vosso canto, e eu aqui sem aça-

42 Cfr. Paul Ricouer, "Il tempo raccontato", Aut-Aut, núm. 216, Milano, noviembrediciembre, 1988, pp. 29 y ss. 
[lanto?

Vinde feras e vinde pássaros, restaurar em sua

[terra este habitante sem raízes,

Que busca no vazio sem vaso os comprovantes

[de sua essência rupestre. ${ }^{43}$

El movimiento del poema es doble y ambiguo: el llamado que busca integrar al habitante sin raíces en su tierra natal reafirma la condición de exilio abismal del sujeto - "vacío sin vaso"; la enumeración de animales y pájaros, muchos de ellos extintos o en vía de extinción, niega la posibilidad de comprobación de una naturaleza primera o de una esencia nativa, una vez que ya es un registro de segundo grado, como suplemento de una corografía anterior- la naturaleza aparece irremediablemente transfigurada por la cultura. Se puede decir que una suerte de catástrofe ecológica del sentido, posible de ser detectada en la carencia de significado para el lector actual de muchos de los nombres enumerados, alegoriza la imposibilidad de instauración de una comunidad imaginada que mantenga, en la unidad, sus rasgos diferenciales.

Pero las imágenes de ruina y dispersión, dando una "nueva belleza a lo que está desapareciendo", ${ }^{44}$ ensanchan las potencialidades de la "na-

${ }^{43}$ Andrade, Boitempo..., p. 53: Onzas, venados, capiguaras, pacas, tamandoas de la/ [corografía del Padre Ángelo de 1881, acutíes, coatíes, / [zorras, perezosos, "papaméis", ¿dónde estáis que os /[ocultáis? // "Mutuns", yacúes, "jacutingas", "siriemas", araras,/ papagayos, pericos, tuíes, que no veo ni oigo, ¿hacia dónde / volastes que os dispersastes? // "Inhapins", "gaturamos", "papa-arrozes", "curiós”, jilgueros / [de silva amena, ¿dónde tanto se oculta vuestro canto, y yo / [aquí sin acalanto? // Venid fieras y venid pájaros, a restaurar en su tierra este / [habitante sin raíces, // que busca en el vacío sin vaso los comprobantes de su / [esencia rupestre.

En A Idade do Serrote se lee: "Yo quería conocer esos bichos, que nos transmitieron portugueses, indios y africanos. Yo quería conocer esos bichos que aparecen siempre en nuestro folklore y que no existían en Minas, por lo menos en Juiz de Fora, el jabotí, el galápago, el tamandoa, la zorra y otros. Según Claudia iríamos más tarde por ese Brasil "guaçu" hasta los confines del Amazonas, a conocer toda esa multitud de bichos. "Cobranoratizei- me" antecipadamente a la vuelta de mi cuarto. Mendes, op. cit., p. 63.

${ }^{44}$ Walter Benjamin, "O narrador. Considerações sobre a obra de Nikolai Leskov", en Magia e técnica, arte..., p. 201. 
turaleza" del texto, ya percibido como una colección de briznas sonoras en busca de un lector que sepa oír y entender el rumor significante. La conexión de los restos de lo que podría haber sido y no lo fue - "poesía de lo revaciado", ${ }^{45}$ en la expresión de Guimarães Rosa, refiriéndose a Minas - avanza, en fin, en el sentido de poder constituir un mundo efectivo de la acción compartida, en el límite y umbral de la nación.

45 Jõao Guimarães Rosa, “Minas Gerais”, en Ave, palavra, Río de Janeiro, José Olympio, 1970, p. 246: "poesia do reesvaziado", en la expresión de Guimarães Rosa sobre el siglo XVII en Minas Gerais, Brasil. 


\section{BIBLIOGRAFÍA}

Anderson, Benedict, Nação e consciência nacional, trad. Lólio L. Oliveira, Sao Paulo, Ática, 1989.

Andrade, Carlos Drummond De, Boitempo \& A falta que ama, Río de Janeiro, Sabiá, 1968.

— Esquecer para lembrar, Río de Janeiro, José Olympio, 1979. Menino antigo, Río de Janeiro, Sabiá, 1973.

ARRIGUCCI JR., DAVI, Enigma e comentário, Sao Paulo, Companhia das Letras, 1987, "Móbile da memória", pp. 67-111.

Arruda, MARIA A Do NAScimento, Mitologia da mineiridade, Sao Paulo, Brasiliense, 1990.

Baudelaire, Charles, Curiosités esthétiques, París, Louis Conard, 1923, "Salon de 1845“, pp. 3-78.

Les fleurs du mal, París, Armand Colin, 1958.

Oeuvres complètes, París, Louis Conard, 1925, "Le peintre de la vie moderne", pp. 49-110.

Benjamin, Walter, Magia e técnica, arte e política, trad. Sérgio Paulo Rouanet, Sao Paulo, Brasiliense, 1993.

BHABHA, HOMI K. [org.], "DissemiNation: time, narrative and the margins of the modern nation", en Nation and Narration, Londres, Nueva York, Routledge, 1990, pp. 291-322.

Bolle, WiLle, Fisiognomia da metrópole moderna, Sao Paulo, Edusp, 1994.

Bomeny, Helena, Guardiães da razão; modernistas mineiros, Río de Janeiro, Ed. UFRJ, 1994.

CAlligaris, Contardo, "Da nação ao triunfo das tribos", Folha de S. Paulo. Ilustrada, 27 de marzo, 1994, p. 13.

CANDIDO, ANTONIO, “Minas não há mais?”, en Seminário sobre a economia mineira, 1, 1982, Diamantina (MG). Anais... Diamantina, 1982, pp. 27-36. 
CANEVACCI, MASSIMO, "Antropólogo italiano cria o étno-cyberpunk", Folha de S. Paulo. Ilustrada, 6 de septiembre, 1995 (Entrevista a Elvis César Bonassa).

DUMONT, LOUIS, $O$ individualismo; uma perspectiva antropológica da ideologia moderna, trad. Álvaro Cabral, Río de Janeiro, Rocco, 1985.

Gagnebin, Jeanne Marie, História e narração em Walter Benjamin, Sao Paulo, Perspectiva, 1994.

Halbwachs, Maurice, La mémoire collective, París, Presses Universitaires de France, 1950.

HobSBAwn, ERIC J., Nações e nacionalismo desde 1780, trad. Maria Célia Paoli e Anna Maria Quirino, Río de Janeiro, Paz e Terra, 1990.

Lima, Alceu Amoroso, Voz de Minas, $2^{\mathrm{a}}$ ed., Revista, Río de Janeiro, Agir, 1946.

Matos, Olgária C. F., Os arcanos do inteiramente outro, Sao Paulo, Brasiliense, 1989.

Mendes, Murilo, A Idade do Serrote, Río de Janeiro, Sabiá, 1968.

MERquior, José GuILHERME, en A astúcia da mímese, Río de Janeiro, José Olympio, 1972, "Notas em função de Boitempo (1)", pp. 44-54.

Miranda, Wander Melo, "Memória e nação", Cenário: Psicanálise e Cultura, núm. 3, Belo Horizonte, 1994, pp. 148-156.

Nava, Pedro, Baú de Ossos, $5^{\mathrm{a}}$ ed., Río de Janeiro, José Olympio, 1978.

Paz, Octavio, Os filhos do barro, trad. Olga Savary, Río de Janeiro, Nova Fronteira, 1984.

POLlaK, Michael, "Memória, esquecimento, silêncio", Estudos Históricos, vol. 2, núm. 3, Río de Janeiro, 1989, pp. 3-15.

Renan, ERnest, Oeuvres complètes, París, Calmann-Lévy, 1947, vol. 1, pp. 887-906, “Qu'est-ce qu'une nation? Conférence faite en Sorbonne, le 11 mars 1882 ".

Ricouer, PAUl, "Il tempo raccontato", Aut-Aut, núm. 216, Milano, noviembre-diciembre, 1988, pp. 23-40. 
Rosa, JoÃo GuIMARÃEs, Ave, palavra, Río de Janeiro, José Olympio, 1970, "Minas Gerais", pp. 245-250.

SANTIAGO, SiLVIANO, "Discurso memorialista de Drummond faz a síntese entre confissão e ficção", Folha de S. Paulo. Ilustrada, 7 de abril 1990, pp. 4-5.

TODOROV, TZVETAN, Nous et les autres; la refléxion française sur la diversité humaine, París, Seuil, 1989.

VATtimo, Gianni, La fine della modernità, Milano, Garzanti, 1987. 


\section{-}

